\title{
Field-Based Art Class: Impact on Creative Personality of Pre-Service Early Childhood Teachers
}

\author{
$\mathrm{Ji}-$ Min $\mathrm{Ko}^{1} \cdot$ Soo-Kyung Yang ${ }^{2}$ \\ Department of Early Childhood Education, Cheju Halla University, Republic of Korea
}

\section{ABSTRACT}

Purpose: To explore how a field-based art class affects the creative personality of pre-service early childhood teachers.

Method: Mixed method descriptive study of students majoring in early childhood education at J University ( $\mathrm{N}=63)$. Research tools included a test for creative personality developed by Ha (2000). A corresponding sampling "t" test was utilized to review the effectiveness of the methods. In addition, reflective writings were introduced to analyse any qualitative aspects because they aimed not only at assessing the quantitative effect through pre-and postplanning of a single group, but also at having an opportunity to know more about experiences of the would-be teachers.

Results: The art classes, designed through extensive discussions among experts. included sharing and appreciation of works, museum tours, art activities applicable to the field, mock classes, and on-site classes for children. Findings demonstrate positive impacts on the creative personality of the would-be teachers: Patience/obsession, humour, self-confidence, and curiosity were displayed among the subjects in a significant manner, while imagination, openness, self-motivation and independence did not show significant differences.

Conclusion: The journals proved to be a meaningful tool to reflect on change of perspective, self confidence and attitude towards an art subject, greater curiosity in the exploration-expression-appreciation processes, developing an open mind to accepting individual differences in children, consideration of preparation about art class reflecting children's interest, patience and coping in unexpected real-class situations. Each journal presented positively the combined experiences associated with a creative personality. The findings suggest that such approaches applied to a field centred children's art class could be relevant to other fields of study for would-be preschool teachers.

Keywords: Field-based art lessons, Pre-service early childhood teachers, Creative personality

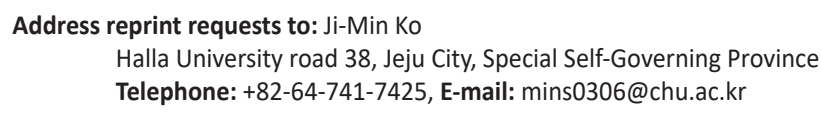

Received: October 8, 2018 Revised: October 29, 2018 Accepted: October 29, 2018 


\section{INTRODUCTION}

\section{Background}

The emergence of personality education emphasizing human virtues is increasing (Lee \& Kang, 2015), and the basic direction of creativity education emphasizes "creativity in the right personality" (MEST, 2012). In other words, personality education and creativity education are not considered separately. The emphasis is on creative personality education that produces new ideas and a personality that emphasizes smooth interaction with the subject (Park, Y., 2001).

New approaches to developing a more creative personality suggest that the attitudes, motivations, and tendencies necessary for creative thinking and behaviour will emerge. As characteristics of creativity personality, Urban (1995) cited concentration, task attachment, motivation, openness, perseverance around ambiguity. Song and Kim (1999) pointed to others such as diversity of interest, curiosity, enthusiasm, adventure, openness, unusual preferences. Ha (2000) refers to selfconfidence, independence, adventure and obsession, curiosity and imagination. The creative personality is not determined solely by the characteristics of the individual but is expressed by interacting with external factors and promoted through individual effort (Lee, G. H., 2002; Park, Kim \& Yi, 2015).

Early childhood teachers with a creative personality are interested in new and exciting things and tend to devote themselves to learning more (Kim \& Seo, 2016). So, creative experiences are made available to the children, providing new and diverse experiences and activities, accommodating the children's unique ideas. It is possible to flexibly address children's individual differences in the development and learning processes(Rodger, 2002;
Bak \& Yoo, 2000). Even in unforeseen circumstances, a positive problem-solving process can lead to satisfactory performance of a given task (Son \& Park, 2012).

Therefore the creative personality of the teacher has an important influence on the capacity of the early childhood teacher to be more immersed in the educational activities that promote the development and learning of the children and to be more professionally confident and positive (Hong \& Yoon, 2018; Sohn \& Lee, 2014; Yan, Kim, \& Hong, 2013). Teachers' creativity is greater when internal motivation and appropriate knowledge and skills are combined (Zhou \& Luo, 2012), Therefore, enhancing the creative ability of pre-service early childhood teachers through systematic education is necessary (Kim. Y. H., 2011; Kim \& Seo, 2016; Park et al., 2005).

To date, research on the creativity of pre-service teachers has focused on the relationship between variables, such as personality type, thinking style, egoresilience, teaching efficacy, and decision-making (Choi, 2003; Hwang \& Kang, 2005; Lee. Y., 2009; Park \& Jo, 2016; Suh, 2003; Yan et al., 2013). The development and application of educational programs for enhancing the creative personality of pre-service teachers is inadequate both quantitatively and qualitatively. Go, Min, and Song (2017) demonstrated that rather than traditional lecturebased approaches, the question-based class emphasizing autonomous participation and permissive questions and discussions has the effect of improving creative personality. Cho, Baek, and Ahn (2014) noted that preservice early childhood teachers who use creativity education using Bernstein's thought tool significantly improved creative thinking and creative personality.

In particular, in the development and application of creative personality education programs for the prekindergarten teacher (Lee, Choi, \& Park, 2013) the 
teacher's creative personality changed positively. They argued for a specific subject on creativity and provided a liberal arts lecture related to creative personality in college education. However, it is also necessary to use teaching methods that promote elements related to the development of creative personality. It is possible to continuously cultivate the creative personality of preservice teachers who have a positive effect on the core competencies required in early childhood education.

Recently, a paradigm shift in the perception of art education has occurred, moving from creativity to personality education as a major subject within curricula (Kim. H. S., 2012; Son, 2009). In art, personality traits of responsibility and consideration, imagination, pleasure, diversity, enthusiasm and other positive elements have been highlighted. The Nuri Curriculum for 3-5 year olds is seeking to cultivate personality traits through various art activities. However, pre-service early childhood teachers are afraid of artistic expression, have a sense of distance from art, and lack confidence in art expression (Kim. M. N., 2011). Art activity itself gives pleasure through experience, and makes a pre-service teacher confident and interested in themselves, so a curriculum that can encourage a creative personality is required (Mun, Ko, \& Hong, 2016).

Kim, H. S. (2012) suggested that confidence in art is created when many parts of the curriculum are devoted to direct experience of artistic activities and that knowledge, skills and creative attitudes can be learned through fieldbased instruction. By not memorizing artistic knowledge or being involved in art lessons centred on fragmentary 'mock' teaching sessions, practical knowledge can be formed through direct experience through field-based children's art classes (Son, Cho, Kim, \& Lee, 2010). It is necessary to examine whether field-based art lessons can help the pre-service early childhood teachers avoid fear of art and envisage how these experiences can enhance the creative personality of pre-service teachers. In this study, we explore how the field-centred art class impacts the creative personality of pre-service early childhood teachers. The study suggests directions and methods for cultivating teachers with creative personality.

\section{Research question}

What is the pattern of creative personality change in pre-service early childhood art teachers resulting from greater exposure to field-centred art classes?

\section{METHOD}

\section{Setting and participants}

University Ethics Clearance was granted. This research centres on 63 Grade 2 students within a 3 year college early childhood program at J University. Collaborative team work commenced on the project involving the fieldbased art classes for 10 weeks from March 2, 2016 to June 15, 2016. First and second semester participants used the "kindergarten," a familiar place for frequent visits to "Observation and Practice" and "Kindergarten Site Linkage" in the first year from 10 to $11 \mathrm{am}$. Observations and studies were carried out between 4 and $5 \mathrm{pm}$. The venues were psychologically comfortable places for participants to freely visit for discussion with cooperative team. 


\section{Design of field experiences}

As Fein (1994) suggested it is desirable to design the field experience and the university class to link the art education offered over ten weeks and activities focused on enhancing the practical skills of the pre-school teachers in actual contexts of practice. In addition, in cooperation with field specialists of early childhood education institutions, evaluation of class plans and preparation for on-site classes occurred. Responses of infants, group, self and peer appraisals were considered.

Over three months, in order to cultivate professional knowledge and skills in art, and to provide successful and varied experiences included observation, various activity experiences for class planning, discussion and analysis, mock classwork informing on-site teaching. Through the process of consultation with two experts in the field, the validity of the artistic teaching method was reviewed and revised. For 10 weeks, the researchers organized fieldbased art classes and a reflective journal. Table 1 provides details of the schedule.

\section{INSTRUMENTS}

Data collection sources were questionnaires focussed on creative personality tests and the reflective journals of pre-service early childhood teachers about art teaching activities.

\section{Table 1. An outline of field-oriented art lessons conducted by pre-service early childhood teachers}

\begin{tabular}{|c|c|c|c|}
\hline Week & Research procedure & Contents & note \\
\hline \multirow{2}{*}{1} & Art appreciation & . Enjoying beauty through works & \\
\hline & Lesson plan Impression-seek-expression & - Understanding various techniques of work & \\
\hline \multirow[t]{2}{*}{2} & Visit to the museum & $\begin{array}{l}\text { - Understanding points of appreciation of works } \\
\text { - After selecting a museum site }\end{array}$ & \multirow{15}{*}{$\begin{array}{c}\text { Create } \\
\text { journals and } \\
\text { reports in } \\
\text { progress }\end{array}$} \\
\hline & Lesson plan Impression-seek-expression & - Pre-activity - Chosen activity- Post-activity plan & \\
\hline \multirow[t]{2}{*}{3} & Kindergarten art area observation & $\begin{array}{l}\text { - Understanding the goals and contents of the art experience area } \\
\text { - Discussion on the art, environment and art area }\end{array}$ & \\
\hline & Lesson plan Explore - Expression - Appreciation & - Collaborative art activities: Using artifacts to construct artistic areas & \\
\hline \multirow[t]{2}{*}{4} & Kindergarten art class Participation observation & $\begin{array}{l}\text { - Teacher- Infant, Infant- Infant Interaction } \\
\text { - Art activities and teacher role sharing } \\
\text { - Understanding art and teaching methods }\end{array}$ & \\
\hline & Lesson plan Explore - Expression - Appreciation & - Listening to music and expressing the feeling with a line & \\
\hline \multirow[t]{2}{*}{5} & Kindergarten art class Participation observation & $\begin{array}{l}\text { - Flat expression development } \\
\text { - Understand the level of development of planar expression through infant works } \\
\text { - Lesson plan }\end{array}$ & \\
\hline & Lesson plan Explore - Expression - Appreciation & - Explore and express texture and colour mixing process of materials & \\
\hline \multirow[t]{2}{*}{6} & Kindergarten art class Participation observation & $\begin{array}{l}\text { - Development of colour expression } \\
\text { - Understanding developmental level of colour expression through infant works }\end{array}$ & \\
\hline & Lesson plan Explore - Expression - Appreciation & - Three-dimensional representation after searching clay & \\
\hline \multirow[t]{2}{*}{7} & Kindergarten art class Participation observation & $\begin{array}{l}\text { Development of stereoscopic expression } \\
\text { - Understanding developmental level of stereoscopic expression through infant } \\
\text { works }\end{array}$ & \\
\hline & Lesson plan Explore - Expression - Appreciation & - Light and shadow detection & \\
\hline 8 & Mock class & $\begin{array}{l}\text { - Age and corresponding semi-determinations } \\
\text { - Preparation of class plan } \\
\text { - Mock Lesson: Instructional Execution / Lesson Analysis for Students }\end{array}$ & \\
\hline 9 & On-the-spot classes for children & $\begin{array}{l}\text { - Review of class plan } \\
\text { - Application for infant classes }\end{array}$ & \\
\hline 10 & Class analysis and evaluation & $\begin{array}{l}\text { On-site teacher evaluation } \\
\text { Presentation and evaluation of application case report }\end{array}$ & \\
\hline
\end{tabular}




\section{Creative personality test questionnaire}

The Creative Personality Test (CPS-R) questionnaire (Ha 2000) was used to measure the creative personality of the pre-school teachers. The questionnaire (reliability .62 to .87) consists of 30 items and eight sub - factors (patience/ obsession ( $\mathrm{n}=5)$, humour $(\mathrm{n}=4)$, self-confidence $(\mathrm{n}=5)$, curiosity $(n=4)$, imagination $(n=4)$, openness $(n=2)$, adventure $(n=2)$, independence $(n=4))$. A 5 point scale from 'not at all' to 'strongly agree' was used for each item; the higher the score, the higher the creative personality of the pre-school teacher.

\section{Reflective journal}

Students kept a reflective journal to freely record their feelings, experiences and thoughts. Reflective journals are suitable for examining the changes of prekindergarten teachers' thinking. Reflections include inhouse conversations about ideas, beliefs, and attitudes to the forefront of their minds while taking field-based art classes (Seo \& Kim, 2009). In addition to the weekly journals, reflective journals also included a summary of their thoughts on art education at the end of the semester.

The number of journals entries varied by individual, but usually 20 were written and submitted to the professor at the end of semester. In addition to the reflective journals, details of consultation with the professor recorded the planning, preparation, implementation and evaluation of the art education for children. Consideration was given to the opinions of field workers in the early childhood education institute and to exchanges of opinions and discussions about the activities of the preparation and activities of the art class.

\section{Data collection and statistical analysis}

The data were analysed for the purpose of exploring the differences and changes in creative personality of pre-service early childhood teachers. First, a pre-test for creative personality was conducted; the researchers explained the purpose and methods of the study to the students who formally agreed to participate in the research. At the end of class, the creative personality post-test was undertaken. Numbers were used for participants for comparison of pre- and post-tests. Three students who did not complete creativity questionnaires were excluded. The quantitative effects were analysed by applying a corresponding sample t-test with a single group dictionary post-design.

Second, analysis of the qualitative data included observation records prepared by the pre-service early childhood teachers, the report writing and the reflective journal(RJ). The data from the reflective journals were analysed by two researchers working together to extract and interpret meaning from sentences or phrases. In order to improve the content validity, other researchers checked the data analysis and categorization, and confirmed the appropriateness of the analysis. Since there was a need to integrate a list of similar sub-themes in the writing process, the first categorization, and cross checked by other researchers for appropriateness, and final categorization agreed upon. Researchers also extracted data showing the process of creative personality change of pre-service early childhood teachers.

\section{RESULTS}

\section{Creative personality pre- and post-test analysis results}

The pre- and post-tests reflected the kind of changes that occurred since the early childhood teachers had received a field-based art art lessons. The results of paired 
t- test are shown in Table 2. There was a meaningful difference in creative personality among patience/ immersion, humour, self-confidence, and curiosity, but no significant difference in imagination, openness, adventure, and independence.

Table 2. Difference between pre-and post-test of creative personality

\begin{tabular}{|c|c|c|c|c|c|}
\hline \multirow{2}{*}{ sub-factor } & \multicolumn{2}{|c|}{ pre } & \multicolumn{2}{|c|}{ post } & \multirow{2}{*}{$t$} \\
\hline & $M$ & SD & $M$ & SD & \\
\hline $\begin{array}{l}\text { patience/ } \\
\text { obsession }\end{array}$ & 2.73 & .65 & 2.89 & .61 & $-2.78 * *$ \\
\hline Humour & 2.81 & .78 & 3.02 & .69 & $-3.91 * * *$ \\
\hline self-confidence & 3.47 & .64 & 3.63 & .59 & $-2.88^{* *}$ \\
\hline Curiosity & 3.24 & .53 & 3.40 & .52 & $-2.50^{*}$ \\
\hline Imagination & 3.66 & .63 & 3.71 & .66 & -.82 \\
\hline Openness & 3.67 & .50 & 3.71 & .53 & -.74 \\
\hline Adventure & 2.92 & .95 & 2.88 & .89 & .41 \\
\hline Independence & 3.44 & .69 & 3.58 & .72 & -1.86 \\
\hline All & 3.25 & .40 & 3.35 & .37 & $-3.50 * * *$ \\
\hline
\end{tabular}

\section{RESULTS}

\section{Change of perspective and attitude on the art subject}

Pre-service early childhood teachers expressed fear of art and felt drawing well was a burden. However, the student (S) was getting closer to art through field-based art lessons and it was recognized that the art was able to be done by anyone, the criterion for good painting was not important and the process of enjoying art was important.

When I first got art classes, I was quite nervous. Because I (thought) How can I teach art to children when I have no talent and no interest in art? (S8, RJ: 2016. 3. 20)

I hate art because it was so difficult. Through the art lessons in children, I felt that art was not far from me, but that I was not trying to reach. (S60, RJ: 2016. 6. 3)

A variety of activities that I have not had in everyday life, such as visiting art museums that I have not normally attended, first-hand pressed flower, sand art, have brought me happy memories of my childhood. I realized that what is important in art is not a wellfinished work but the things Ifeel and the process during work. (S3, RJ: 2016. 6. 9)

I have changed from fears and rejections of art, boring and difficult thoughts to various interesting and funny activities. I have a lot of time to think about how to make my work and how to make it more wonderful. ( S42, RJ: 2016. 6. 5)

I had a wall for art because I did not think I could draw well. However, I was very pleased to do this art work. Beautiful works come out by chance, and I have become more familiar from the subjective point of 'doing art' while working in various ways. (S18, RJ: 2016. 5. 25)

Pre-service early childhood teachers developed new and interesting ideas through various art experiences, and increased confidence in the art subject. This positive attitude change had a positive impact on freely expressing one's feelings and developing creative ideas.

\section{Self-confidence through an art subject}

The art lessons were able to provide a variety of artistic experiences within limited spaces, thus creating a link between art and life that is far from real life. This class environment encouraged students to develop positive attitudes toward new and diverse experiences through the subject of art.

I was able to feel different shapes and feelings in each flower while taking flowers directly from the classroom. We dried the collected flowers well and displayed the pictures together with our team members using the pressed materials. It was possible to express them only with the flowers without using various art tools and materials (S10, RJ: 2016. 4. 22). 
I did a lot of art activities, but there was hardly anything to appreciate other people's works. I was able to feel the freedom of expression rather than being trapped in something while admiring the work of the painters in the museum. (S12, RJ: 2016. 6.15)

It is not only art to paint, but art to play shadow, and it is also art to paint acrylic water on my furniture in my room. Until this time, I was only thinking about art in a narrow sense. Through the arts, I realized that the creative work that contained my thought was - It shows exactly what the emotion expresses in the picture. (S16, RJ: 2016. 6. 3)

Art is not just dirty work clothes, it is an activity that is not funny, but it is an activity that can express one's own thoughts and feelings and create another my own world. (S24, RJ: 2016. 6. 2)

In a field-based art lesson, pre-service early childhood teachers found the elements of interest and pleasure in the art and put their thoughts into their works. As a subject, they became more confident in free expression of art as they immersed themselves in art activities and completed their works.

\section{Curiosity added in the exploration-expression appreciation process}

In the process of exploring the art materials, the preservice early childhood teacher was concerned about the kind of story material to express. Such curiosity and interest led them to express their thoughts and feelings more clearly. The more focused on curiosity from the material search, the more they became immersed and experienced the joy and fulfilment feeling in the completion process.

The activity of mixing various liquids in the powder pigment was good to see how the texture was different and know how the colour changes depending on how much water is mixed with the paint; they do this with the children. (S7, RJ: 2016. 4.20)

Wet watercolours painting - did not really know what to do. I did not imagine that the paper was wet and I was drawing a picture on it. However, when I painted the picture above, the boundary was not clear and spread softly, so it looked better and it felt better. It was amazing to spread softly. (S40, RJ: 2016. 4. 27)

I was amazed at the wonderful work that I had assembled in the usual PET bottles that I had forgotten. I want to make new works with children by using things that can be expressed around art. (S3, RJ: 2016. 4. 26)

I was delighted to express what I wanted with clay, regardless of the subject. Providing children with clay experience will also help them feel the clay touch and stimulate various senses as well as the development of children' small muscles. (S25, RJ: 2016. 5.10)

As I talked about my work with my team members, I was able to understand the intention of the artist more and understand the feelings in the work. I could see it as a simple picture, but I realized that it contained various emotions and intentions. (S21, RJ: 2016.6.3)

The field-based art lessons were connected to the process of expression delicately through sufficient exploration and appreciation. These experiences have enhanced children's curiosity and students' educational expectations about what materials they can provide and how to apply, and how to express them. In addition, in appreciation of the works of other friends, they were able to understand the world from different perspectives and share creative and novel ideas expressed in the works. 


\section{An open mind to accept individual differences in children}

Pre-service early childhood teachers recognized the importance of proper scaffolding in order to develop to the next stage, even though there are individual differences among children at the stage of art development even in the same age group. But, the early childhood teachers observed in Class Participant Observation Reports (PORs) that the education provided limited activities and materials to children. They were unhappy that children did not have many opportunities to freely express themselves. It was time to think seriously about how to respond to children who are interested in art or talented children, and to those who are more reluctant to express art.

The interesting thing about observing the kindergarten classroom was that the developmental stages of the same kind of children varied. But I was regretting that it was a picture of the child at the schematic representation stage - I did not see the baseline due to limited activity. I felt that art activities were necessary for children to express (themselves) freely. (S4, POR: 2016. 5. 10)

I attended art classes. In response to the teacher's question, "What can I see in the spring?", The children answered many things, such as butterflies, pupa, earthworms, forsythia, and azaleas. So I thought that I could see many expressions of the activity. However, the ground and the buds were displayed in advance in the activity book, and the children expressed the butterflies and flowers suitable for the background picture, but it was very difficult to find various insect pictures. (S22, Class POR: 2016. 4. 6.)

Materials were too limited when performing art activities. For example, the sea urchins were made in advance and the abalone was also made, so the children made universal things and did not have creative works. Sometimes, a child made his/her own abalone paintings, but the results were similar and did not seem to be so interesting. (S13, Class POR: 2016. 4. 13)

I thought children liked art. There were children who expressed pictures more than I imagined, but there were children who did not like to draw. I felt that it is important to nurture self-confidence rather than drawing well on art. (S51, Class POR: 2016. 4. 5)

Through the field-based art lessons, the pre-service early childhood teachers were able to freely express their own topics using art materials and to experience openness and diversity while admiring the works of others. In addition, through the kindergarten observation, even though age ranges differed, individual differences in art expression existed, and they felt that an open environment was needed to accommodate these individual differences. They recognized that it is important for teachers to provide the artistic medium and environment where children can express themselves freely and to encourage children to express their thoughts.

\section{Consideration and preparation about art class reflecting children's interest}

Pre-service early childhood teachers have been led to the idea of enjoyable art classes through various art experiences and sufficient opportunities for exploration and expression, and began to consider the application of art classes for children. In order to plan an art class that reflected the interests of children and encourage creative thinking, they shared ideas with their team members and expanded their range of thinking and were able to find answers to ambiguous questions.

I used to think of light activity as the activity to compare 
colours or make shadows using cellophane. However, through the light activity, transparent objects and opaque objects were seen through, and transparent hemispheres were also painted with cellophane and name pen. Sufficient experiences with the material led the children to think about how to apply the lessons. And as the teacher explores the material and experiences the art directly, I felt that I could have more fun lessons. (S17, RJ: 2016. 6.14)

Although I have been doing mock lessons since the first grade, it is the first time that the lessons for actual children, so I became worried about setting the activities. Questions such as "What activities should be able to induce the child's interest well?", "How can I proceed creatively," and "How can I make a more effective speech?" continued (to arise). (S22, RJ: 2016. 5. 25)

I also talked about my feelings about art activities with my team members and thought about what kind of activities would be applied when I applied them directly to infants. As I continued to think about activities together (with others) rather than alone, I think that my point of view of art activities has changed a lot. (S8, RJ: 2016. 6. 13)

I realized that even if I had planned an interesting class, if I could not prepare properly, it would be difficult to make the class successful. It was just a pattern only for mock lessons in the same class. In fact, I really felt that I needed a thorough preparation for classes in order to teach the children. (S23, RJ: 2016. 6. 9)

The field-based art lessons enabled the pre-service teacher to learn a lot while preparing the lessons for the children rather than the teacher. The more they worried and thoroughly prepared, the more they realized that it could be a lesson that inspired children's interest and bring out creative ideas that can only come from children. The quality outcome of the lesson was a realization that 'taking the time to feel the ordinary truth' that it does not minimise the quality of the teaching.

\section{Patience and coping in unexpected real-class} situations

Although pre-service early childhood teachers consider various situations within the planning of the lessons for the child, even when they are actually in progress, they have difficulty in responding to the need for unexpected immediate responses to individual children. The ability to cope with this situation needed development, and they collaborated with the team members, rather than alone to ensure that the teaching activities were completed well. They felt they was still lacking in mature coping mechanisms, but they also felt a sense of accomplishment when they saw the child immersed in their activities and working creatively.

I realized that the children responded to the anticipated responses and were proud of it to some extent, but I thought that I had to prepare a countermeasure by considering the number of cases that could occur, such as pouring water during the lesson planning. (S15, Class report for children: 2016. 5. 30)

It (Art) is really different from the expected class plan and actually teaching with infants. The idea of the activity itself is good, but I think about various situations and make a thorough correction and amendment, and when I became a real teacher, I thought that I could apply it to class. (S18, Class report for children: 2016. 5.31)

When I was practically practicing a make-over class, the child's words and unexpected responses made me 
embarrassed, but it was a meaningful time. Especially in the middle, I was really surprised to have a child who would make a boomerang instead of a top, but I was able to get the opinions of the infant in a casual way. (S44, RJ: 2016. 5. 25)

The children began to draw the desired picture on a stationary paper or to make a hole with a drill without a sketch. The infant pulled out the hole looking at the paper toward the sky

T: What do you see?

C1: I see trees, and I see teachers.

C2: It seems to be in a bee house.

C3: But when I touched it, it seemed like a letter that people with disabilities touched.

C4: I can see the sky through the hole, but I'll block the sunlight.

(S30, Class report for children: 2016. 5. 26)

The pre-service early childhood teacher recognized the unexpected and interesting children's reactions and thoughts through the field-based art lessons, and it was important to listen to the children's words and react appropriately. Theoretically, we have learned about the developmental characteristics of the child and need more patience and field-based experience in order to cope positively with flexibility and need a deeper understanding of the characteristics of individual children.

\section{DISCUSSION}

The purpose of this study was to explore the changes in the creative personality resulting from exposure to the field-based art lessons and to draw implications about approaches to learning. First, as a result of applying the fieldbased art lesson, there was a difference between the preand post-tests in creative personality that was improved as a whole. This is consistent with Go et al's (2017) findings that the question-based lesson that emphasizes autonomous participation, permissive questions and discussions has a significant effect on the creative personality of pre-service early childhood teacher. It can be seen that lessons with effective techniques can improve the creative personality of pre-service early childhood teachers and increase the effectiveness of teaching and learning.

In the present study, it was found that the questionbased discussion class had an effect on the task attachment, the uniqueness of judgments, the risk supervision, and the openness of the thinking, while it appeared to affect patience/obsession, humour, self-confidence and curiosity (Go et al., 2017). In the study of Cho et al (2014), there was a statistically significant difference between the groups in patience, obsession, humour, curiosity, and adventure among creative personality. The reason why the sub-factors showing significant differences in creative personality are different is that the element or content of creative personality emphasized in curriculum content is slightly different, and this is the result of learning activities advocated by the program. Thus, we can see that creative personality is changeable or able to be developed, depending on how interaction with the elements is made accessible through the classroom activities.

The important thing to look at here is 'self-assurance', one of the elements of creative personality. Self-confidence is related to the expectant teacher efficacy (Lee, Y. 2009). Teacher efficacy is related to the beliefs accumulated through long experience as a teacher. It is not easily changed through a small experience in a short period of time, but the positive change in 'self-confidence' has 
an impact. As pre-service early childhood teachers, the burden of engaging in art, the rejection of the art forms, and the boredom disappeared, and it became a more and more interesting activity, and the self-confidence about the art class increased. It was thought that more confidence in the teaching method arose through gathering various pieces of information for solving the problem situation while worrying about the art class, or cooperating with the teachers and finding the solution more easily through collaboration.

The patience/attachment sub-factors are consistent with the findings of Go et al. (2017) and Cho et al. (2014). This experience had a sense of accomplishment by solving the difficulties that arise during the process of planning, conducting, and evaluating the art education activities for children through cooperation. If it was possible to flexibly cope with unexpected problem situations it was estimated that the ability to commit to the task and complete it to the end was improved. In the study of Ma and Ko (2002), preservice early childhood teachers experienced 'difficulties in controlling behaviour of children', 'difficulty of decision making' and 'difficulty of interaction'. This difficulty was explained by the fact that pre-service early childhood teachers had to cooperate with their colleagues in case of conflict situations in the mock class. Through this, the field-based art lessons in connection with mock classes and early childhood education enabled students to recognize the need for a collaborative community (Kim, H. S., 2006; Kim, Y. C., 2005)

Positive educational experiences that satisfied curiosity while positively participating in the field-based children's art classes promoted positive change in the following orderhumour, self-confident, patience/obsession, and curiosity, which are sub-areas of overall creativity personality. There was no statistically significant difference between imagination, openness, adventure, and independence. Imagination created a virtual situation. Through this imagination, the actual experience, emotion and abstract thinking are gathered within a sympathetic mind. In this sense, human imagination includes not only emotional but also cognitive aspects (Kim, E., 2013), Openness, independence, and creativity tend to be included as examples. It is considered that it is necessary to promote the imagination of teachers and create an open learning atmosphere until such attitudes and tendencies become habitual. It is believed that if the method and learning environment for on-the-spot children's art done in one semester are continuously provided to the prekindergarten teacher, it will bring about a positive change in a manner consistent with the creative personality. Therefore, it is necessary for pre-service early childhood teachers to evaluate their own creative ability positively and to provide an educational environment in which they can immerse themselves in their work so that they can develop their own capabilities through cultivation of a more creative personality.

In this study, we investigated through the qualitative analysis of the reflective journals and through the analysis of the quantitative effect of the single group dictionary post-mortem through the voices of the pre-kindergarten teachers about the changes in their creative personality. The reflective journal analysis, that can depict the teacher's perceptions of any change about art and the role of the art class, was classified into 6 categories. Educational implications are as follows.

First, there was a change of perspective and attitudes about the art subject. The pre-service early childhood teacher was able to break their stereotypical view of art through engaging with the field-based children's art class and to express freely their feelings of vague fear 
and the need for artistic perfection. In other words, art was perceived as a privilege given only to people with artistic talent, not them, but this was an opportunity to dramatically change their points of view on art through art experience in everyday life. This reduced their fear and rejection of art and created more interest in art itself. One of the many conditions that define the quality of education is that it is educationally meaningful. In this instance the educational experience changed the perceptions on the art subject with respect to the need to enhance the teacher 's ability or professional qualities. This occurred because of the positive perceptions of the art subject which can positively impact not only the creative personality of the pre-kindergarten teacher but also the qualities and competence of the pre-kindergarten teacher.

Second, there was an improvement in self-confidence with an art subject. As the pre-service early childhood teachers perceived art lessons as more difficult as fieldoriented children's art lessons progressed, they began to show a change in expressing happiness through various art experiences and actively expressing them. In this way, if the pre-kindergarten teacher thinks positively about their creative ability, this positive awareness can provide the environment for the child to express themselves with various experiences and free ways (Son et al., 2010). Therefore, pre-service early childhood teachers improved their confidence and senses of humour in creative personality to create interesting thoughts.

Third, there was a level of curiosity added to the exploration-expression-appreciation process. The pre - service early childhood teacher tried to explore the material within the subject and to express what kind of story material it was. The teachers expressed thoughts and feelings more clearly. In addition, becoming more immersed in their work while radiating an inner desire to express it without being bound to the subject objectives, feeling a sense of joy and accomplishment in the results of this process. In addition, while appreciating the finished work, teachers were able to understand the world in which they experienced each other and to find meaningful and valuable things in it (Kim, H., 2012). This process within the aesthetic search, expression, and appreciation positively impacted the creative personality of the pre-kindergarten teacher in a similar way to the research results reported by Mun et al. (2016) that is, the search within art activity for recognition of aesthetics had a significant effect on the curiosity of creative personality.

Fourth, there was an open mind to accept individual differences in children. It is necessary to understand the stage of development of the children, so one can help the growth and development of the child in the processes in the training the preterm children teacher, and to establish the role and the qualification of these teachers (Lee, Gong, \& Hyun, 2013). The pre-early childhood teachers who participated in this study got a better understanding of the various ideas of the infants through the practical experience related to the theoretical education about the developmental characteristics of the children and the kindergarten experience linkage. In addition, they responded positively to the child's thinking as they learned how to accept the child' s unexpected responses and ideas without embarrassment. In this way, understanding the curriculum from planning to evaluation through the field-based children's art classes, and the experience of knowing and supporting the developmental characteristics of the child, positively influenced the openness of the creative personality of the pre-teacher (Park \& Jo, 2016).

Fifth, there was consideration of the need for 
preparation of art classes reflecting children's interests. The preliminary early childhood teacher does not only recognize the importance of painting while completing the work by considering the material and expression, but also ideas on how to use the on-site class for infants. The materials and expression of art education activities are expanding (Seo \& Kim, 2009). The pre-service early childhood teachers are not only providing limited topics for infants but also various kinds of art for children to freely imagine and express themselves. One had also come to think seriously about the role of the teacher in studying the media and eliciting the thoughts of young children as a result of this study. The field-based art education provided a positive change for the pre-service teachers to prepare their art activities based on their understanding and knowledge of the developmental level of the child and to have confidence to consider the points to be considered by art professors (Park, E., 2015).

Sixth, there was a level of patience and coping demonstrated in unexpected real-class situations. Although there are limitations in defining the cognitive level of child givn the level of expereirence of preliminary teachers in this situation where the mock class was set up, it was found that the individual characteristics of children are significantly different from the actual class' children (Ma \& Koh, 2010). There have been difficulties in responding to the unexpected immediate responses of the individual child. An ability to cope with this situation was needed, and they collaborated with the team members for guidance. They were not alone in their efforts to ensure that the teaching activities were completed well. Providing students with the opportunity to experience the integrated theoretical and practical experience and direct and indirect teacher role experience will enable them to have a real understanding of art education content, teaching methods, infant development levels, and to recognize the importance of teacher's role. This experience may also have had a positive impact on the efficacy of art professors (Park, E., 2015).

In this study, it was found that the field-based art lessons had a positive effect on the pre-kindergarten teachers' combined experiences with creative personality. Therefore, it is suggested that pre-service early childhood teacher's preparation needs to be diversified continuously through a range of courses in order to cultivate creative personality. Based on the results of this study, the following limitations are:

First, the study is limited in the extent of the generalization of research results because it examines the effect of pre-service early childhood teachers 'experiences in field-based children' s art class during one first semester timeline.

Second, this study was conducted for students in the second year of a college program. In future research, it will be necessary to draw out practical opinions about fieldbased college classes that can foster creative personality as pre-kindergarten teachers by linking with other subjects.

\section{REFERENCES}

Bak, B. G., \& Yoo, K. S. (2000). Relationship structure between creativity and intelligence. Journal of Education Psychology, 14(2), 235-261.

Cho, H. S., Baek, S. S., \& Ahn, Y. K. (2014). Creativity education using thinking tools of Bernstein on improvement of creative thinking and creative personality of pre-service teacher`s. Children's Media Research, 13(1), 247-276.

Choi, J. H. (2003). Creativity in thinking styles and desicion making. Unpublished master's thesis, Sookmyung Women's university, seoul, Korea.

Fein, G. G. (1994). Preparing tomorrow's inventors. In S. G. Goffin, \& D. E. Day(Eds.). New Perspeatives in early 
childhood teacher education (pp. 135-144). NY: Teachers College Press.

Go, H., Min, H. D., \& Song, J. S. (2017). The effects of questioncentered havruta lesson on the creative personality and problem-solving ability of preservice early childhood teachers. The study of Learner-Centered Curriculum and Instruction, 17(13), 253-278.

Ha, J. H. (2000). The developmental study of creative thinking and creative personality from childhood to youth. Unpublished doctoral dissertation. University of Sungkyunkwan graducate school, Korea.

Hong, J. M., \& Yoon, S. K.(2018). The relationship between preservice early childhood teachers' creative personality and ego-resilience. The journal of humanities and social sciences 21, 9(1), 321-332.

Hwang, H. S., \& Kang, S. H.(2005). Relationships among thinking styles, psychological types, and creative personality in pre-service early childhood teachers. Open Early Childood Education, 10(2), 131-150.

Kim, E. J.(2013). A psychoanalytic study on creativitypersonality education and child development. Journal of educational studies, 44(4), 171-190.

Kim, H. J., \& Seo, H. A.(2016). The meditating effect of creative personality on the relationship between teaching efficacy and teaching performance in early childhood teachers. Early Childhood Education, 36(1), 253-272.

Kim, H. S(2006). On becoming "the teacher": newly appointed preschool teachers' teaching stories. Early Childhood Education, 26(2), 283-308.

Kim, H. S.(2012). Creativity and character education through arts education. Journal of art education, 32, 1-29.

Kim, M. N.(2011). Creative art teachers' classroom research method for their creative art lesson: Art-based classroom research. Formal Education, 4, 1-22.

Kim, Y. H.(2011). A study on the viewpoint of children and teaching profession of new students who are pre-service early childhood teachers, Child Education, 30(3), 69-78.

Lee, G. H. (2002). A study on creative thinking ability and creative personality of 4,5 year old children. Journal of Educational Psychology, 16(3), 147-160.

Lee, G. H., \& Kang, K. L. (2015). A study on the effects of the creativity-personality education programs for pre-service secondary teachers. Accident development, 11(3), 107-141.

Lee, J. R., Gong, E. H., \& Hyun, Y. S. (2013). Relation analysis in art background factors, art teaching efficacy and perceptions of art education of preliminary preschool teachers for art education improvement. A Study on Basic Formation, 14(5), 397-406.

Lee, K. M., Choi, Y. J., \& Park, S. J. (2013). Development of creativity and personality educational program for preservice early childhood teachers and its effects. Children's Media Research, 12(2), 73-96.

Lee, Y. M. (2009). Creative personality and teacher efficacy of pre-service kindergarten teachers. Journal of Korean child care and education, 5(2), 1-20.

Ma, J. S., \& Koh, E. H. (2010). A study on pre-service early childhood teachers' experiences in simulated instruction and field practice. Early Childhood Education, 30(1), 249271.

MEST(2012). Creative education program for the interior design of kindergarten. Seoul: Ministry of Education and Science Technololgy.

Mun, B. H., Ko, E. B., \& Hong, H. K.(2016). The effects of creative crafts and appreciation activity of pre-service preschool teachers on their aesthetic attitude and creative personality. Open Early Childood Education, 21(4), 179200.

Park, E. J. (2015). The effect of the integrated art teacher education of exploration, expression and appreciation on pre-service early childhood teachers ' art teaching efficacy. Journal of Early Childhood Education, 19(4), 29-49.

Park, J. Y., \& Jo, E. M. (2016). The mediating effect of play teaching efficacy on the relationship between teaching competence and creative personality in pre-service early childhood teachers, Journal of Parent Education, 8(2), 137148.

Park, S. H., Kim, K. W., \& Yi, H. S. (2005). The relationships between creative personality and creative teaching performances of early childhood teachers. Journal of Future Early Childhood Education, 12(4), 165-185.

Park, Y. T. (2001). The analysis of meaning of creativity, personality, and creative personality. Resarch Review, 29(1), 
23-50.

Rodgers, D. B. (2002). Supporting autonomy in ypung children. Young Chilren, 53(34), 75-80.

Seo, S. J., \& Kim, H. (2009). An analysis of early childhood education pre-service teachers' understandings of creative education in their reflection journals. Open Early Childood Education, 14(5), 205-227.

Sohn, S. Y., \& Lee, J. H. (2014). Differences in pre-service teacher perceptions on creativity education based on creative personality and practice experience. Journal of the Korean Association of Pediatrics, 14(2), 59-81.

Son, E. J., \& Park, Y. T. (2012). The effect of teachers' efficacy and creative personality on child-care teachers' job satisfaction. Journal of Early Childhood Education \& Educare Welfare, 16(1), 233-253.

Son, J. H. (2011). Integrated Curriculum of Visual Culture for Creativity and Character Education. Elementary Education Research, 24(3), 195-216.

Son, W. K., Cho, H. J., Kim, O. J., \& Lee, H. S. (2010). Exploring a change of pre-service early childhood teachers` knowledge through a field-based art Lesson. Early Childhood Education, 30(4), 319-339.

Song, I. S., \& Kim, H. S. (1999). An exploratory study of the establishment of concept on creativity. Journal of Educational Psychology, 13(3), 93-117.

Suh, M. O. (2003). Study of the relationships that preservice teacher's gender and major on thinking styles and creative personality. Pedagogy research, 41(4), 259-293.

Urban, K. K.(1995). Creativity-a componential approach Post conference China meeting of the 11th world conference on talented children. Beijing, China, August. 5-8.

Yan, Y. H., Kim, H. J., \& Hong, S. Y. (2013). Possible associations of nursery and kindergarten teachers' ego-resilience with their creative personality. Korean infant and child care, 78, 27-55.

Zhou, C., \& Luo, L.(2012). "Group creativity in learngin context: Understanding in a social-cultural frame and methodology." Creative Education, 3(4), 392-399.

I would like to express my very great appreciation to professor Margaret McMillan, the University of Newcastle Australia, for her valuable and constructive suggestions in writing of this paper. Her willingness to give her time so generously has been very much appreciated. 
